\title{
Synthesis of Poly(benzyl ether) Dendrimers Containing Core Diversities by Click Chemistry
}

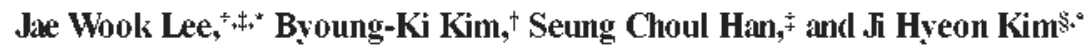 \\ Department of Chemistry and $\ddagger$ Department of Medical Bioscience, Dong-A Universitw, Busan 604-714, Korea \\ E-mail: jlee'odonga.ack' \\ "Department of Chemical and Bio Engineering. Kunngw University, Seongnam 461-701, Korea \\ ${ }^{*}$ E-mail: jihyeonäkumgwon ackr \\ Received September 2, 2008, Accepted Nowember 21, 2008
}

\begin{abstract}
General, fast, and efficient methods for the synthesis of Frechet-type dendrimers having core diversities were

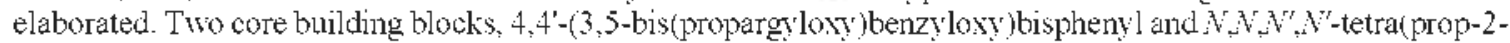
ynyloxycarbonylethyl)-1,2-diaminoethane, were designed to serve as the alkyne functionalities for dendrimer growth via click reactions with the azide-dendrons. The synthetic strategy involved an 1,3-dipolar cycloaddition reaction between an alkyne and an azide- functionalized Frechet-type dendrons in the presence of $\mathrm{Cu}(\mathrm{I})$ species which is known as the best example of click chemistry
\end{abstract}

Key Words: Alkỵne. Azide. Click chemistry. Fréchet-type dendrimers

\section{Introduction}

Dendrimers, which are prepared by repetition of a given set of reactions using either divergent or convergent strategies. are highly branched and regular macromolecules with well-defined structures and have served as functional objects in nanoteclunology and nanoscience. ${ }^{1,2}$ The convergent approach to dendrimer sy'nthesis introduced by Frechet and co-workers revolutionized the synthetic approaches to monodisperse dendrimers. ${ }^{3.4}$ The convergent methodology installs the core in the final step. enabling the incorporation of functionalities. It provides greater structural control than the divergent approach due to its relatively low number of coupling reactions at each growth step. The ability to prepare well-defined (un)symmetrical dendrimers is the most attractive features of the convergent synthesis. The convergent approach allows for a large degree of chemical diversity such that functional groups can be incorporated at nearly central position in the dendritic architecture.

The reactions employed in the synthesis of dendrimers should be highyielding without any side reactions. Well known processes, such as the Michael reaction. Williamson ether synthesis. amidations and reductions have been used extensively in the synthesis of dendrimers. ${ }^{4}$ Recent solid chemistry is the click chemistry which is the copper-catalyzed 1,3-dipolar $\mathrm{cy}$ cloaddition reaction between alkyne and azide developed by Sharpless and Tomoe. This reaction is characterized by mild and simple reaction conditions. reliable 1.4-regiospecific 1,2.3-triazole formations. and tolerance towards water as well as a wide range of functionalities. and is clearly a breakthrough in the synthesis of dendrimers ${ }^{5 \%}$ and dendritic and polymer materials. ${ }^{8.10}$ In the convergent synthesis of the dendrimers. two feasible methods are the fusion of two dendrons and the stitch of multi-functional group with dendrons. We have developed the fusion and stitching methods for the synthesis of symmetric and unsy'mmetric dendrimers and diblock codendrimers using click chemistry between an alky ne and an azide. Herein we report the synthesis of Frechet-type dendrimers containing core diversities by the stitching method of dendrons with tetracore moieties (Figure 1). Because of the highyields and lack of byproducts provided by the click chemistry for stitching together dendrons and core unit, the various dendrimers having functional building block at core could be obtained easily and shown the characteristic behaviors.

\section{Results and Discussion}

The inward growth employed by the convergent sy nthesis is ideally suited for the attachment of diverse core moieties. ${ }^{4}$ As a result. building dendrimers via the convergent approach allows for the synthesis of symmetric dendrimers and for specific incorporation of function into the dendrimer interior. The synthetic strategy for Frechet-type dendrimers. linked by the triazole units, utilized a convergent method using the azidofunctionalized Frêchet-type dendrons 1-Dm and the tetraalkynes (Figure 1). To efficiently connect the azide focal point Frechet-type dendrons with core units. the șinthetic approach selected is based on the click condition using $\mathrm{Cu}$ (I) species. ${ }^{11}$ The azide focal point Frechet-type dendrons 1-Dm $(m=1 \sim 4$ : generation of dendron. Figure 1) are synthesized according to the reported procedure. ${ }^{7.12}$ The $4,4^{\prime}-(3,5$-bis(propargy losy) benzyloxy)bisphenyl 2 and $N, N_{1}, N^{\prime}, N^{\prime}$-tetra(prop-2-y nyloxycarbonylethyl)-1.2-diaminoethane 3 . designed to present alkyne functionalities available for dendrimer growth wia click reactions with the dendrons, were synthesized readily from and the bis-alkylations of 4,4-bisphenol with 3,5-bis(propargyloxy) benzyl chloride ${ }^{\gamma}$ in the presence of a base and the Michael addition of 1.2-dianinoethane with propargyl acrylate. respectively.

To test the effectiveness of the dipolar cycloaddition reactions of the tetra(alkynes) core 2 and azide-dendron 1-D1 (Scheme 1). we have screened with several conditions using various $\mathrm{Cu}(\mathrm{I})$ sources in different solvents. ${ }^{5.11}$ We have found that the reaction conducted from the condition of $5 \mathrm{~mol} \%$ of 
$\mathrm{CuSO}_{4} \cdot 5 \mathrm{H}_{2} \mathrm{O}$ with $10 \mathrm{~mol} \%$ of sodium ascorbate with respect to the alkyne in a $4: 1$ solvent ratio of D. $10 \mathrm{I} \mathrm{I}_{2} \mathrm{O}$ for $4 \mathrm{~h}$ at 50 ${ }^{\circ} \mathrm{C}$ afforded the desired product 4-G1 in yield of $96 \%$. The disappearance of tetra(alkynes) 2 as well as generalion and disappearance of the mono-, di-, and tri-triazole derivatives were monitored by TI,C runs of the reaction mixlure. The dendriner 4-G1 was puritied by column chromatography and the structure of dendrimer was contirmed by ${ }^{1} \mathrm{H}$ and ${ }^{13} \mathrm{C}$ NMR spectroscopy, IR spectroscopy, and FAl3 mass spectra. Given the success in the synthesis of first generation dendrimer. we expanded this reaction to get higher generation dendrimers with 5 $\mathrm{mol} \%$ of $\mathrm{CuSO}_{+} \cdot 5 \mathrm{I}_{2} \mathrm{O}$ with $10 \mathrm{~mol} \%$ of sodium ascorbate with respect to the alkyne in a 4:1 solvent ratio of [DMF to $\mathrm{H}_{2} \mathrm{O}$. Reactions of the tetra(alkynes) 2 with 4.4 equiv of 1-D2 and
1-D3 aftorded the dendrimers 4-G2 and 4-G3 in yields of 96 and $95 \%$, respectively. alter 6 and $7 \mathrm{~h}$, which were separated by column chromatography. In case of 1-D4. the triazole dendrimer 4-G4 was oblained in 97\% yicld after $7 \mathrm{~h}$. This comparative efficiency of the click methodology is emphasized by the synthesis ol the dendrimers with the tailed madio core units. Therefore this approach may provide new methodological insight into introduction of various functional cores and would greatly contribute to researches on the application side. We are now investigating for self-emissive dendrimer with a fluorescent or phosphorescent probe in core region.

Structural characterization of the dendriners 4-Gm with ${ }^{\mathrm{H}} \mathrm{H}$ NMR. ${ }^{\text {' }} \mathrm{C}$ NMR. and IR spectroscopy showed no deliects due to incomplete reaction. From the II N.MR spectra $\left(\mathrm{CDCl}_{3}\right)$, the<smiles>Cc1cc(C=N)cc(OCCOCCO)c1</smiles><smiles>COc1cc(COc2cc(CN)cc(OCc3cc(OC)cc(OC)c3)c2)cc(OC)c1</smiles><smiles>C#CCC1C2C3CC4C5C3CC2C5C14</smiles>

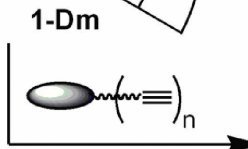
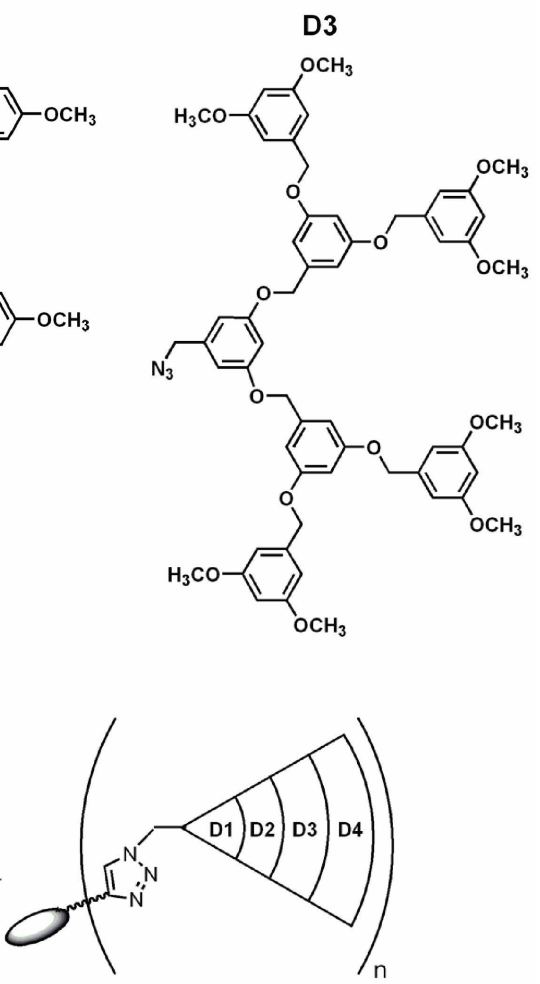

D4

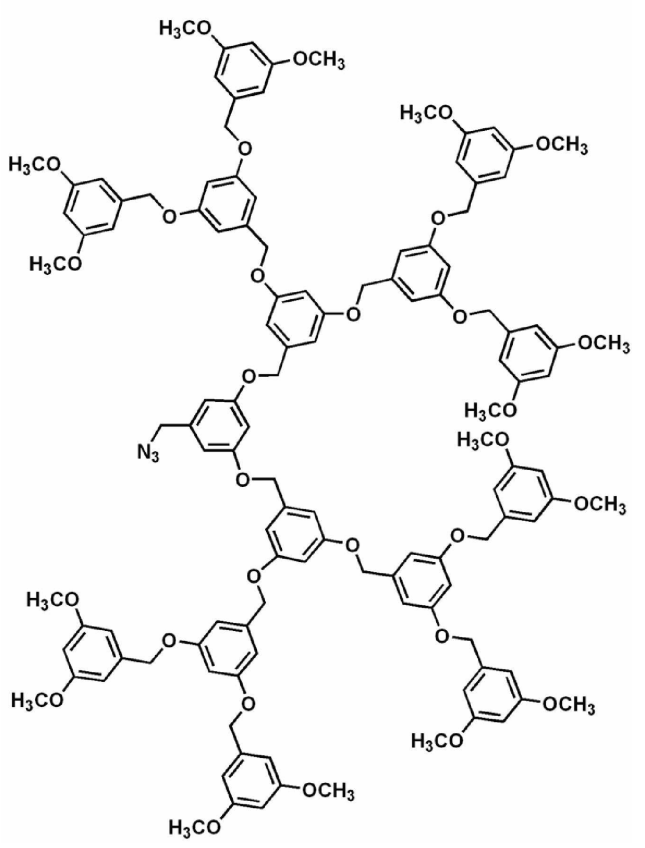

Figure 1. Structures of dendrons 1-Dm and synthetic strategy of dendrimers.<smiles>C#CCOc1cc(C)cc(OCC#C)c1</smiles>

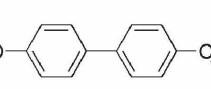

2

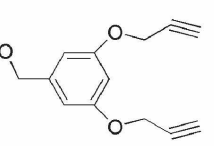

$+$

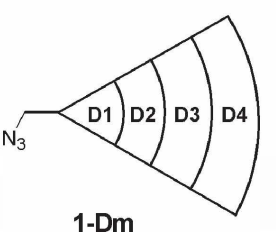

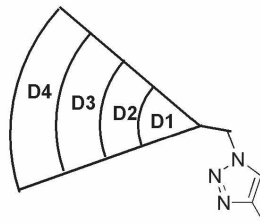

N

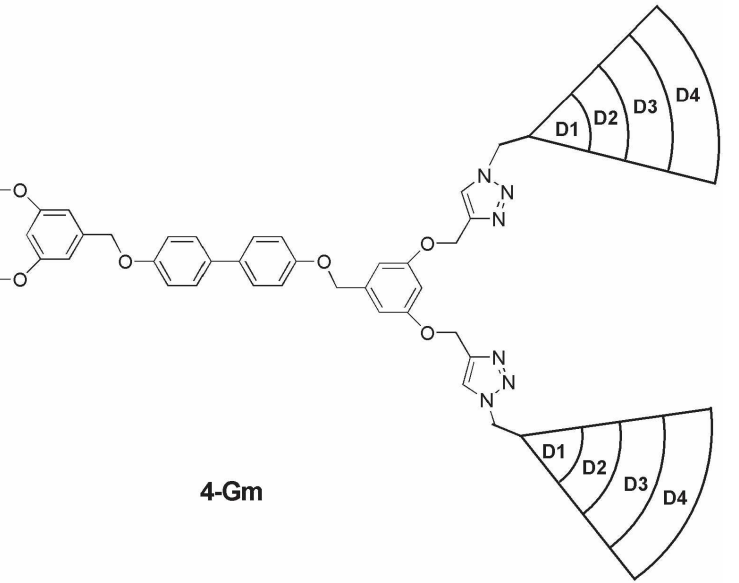

Scheme 1. Reagents and conditions: $20 \mathrm{~mol} \%$ of $\mathrm{C}^{\mathrm{uSO}} \mathrm{SO}_{4}-5 \mathrm{H}_{2} \mathrm{O} / 40 \mathrm{~mol} \%$ of sodium ascorbatc. [JMF $/ \mathrm{H}_{2} \mathrm{O}(4: 1), 50 \% \mathrm{C}$. 
peaks of the methylene protons adjacent to the nitrogen of triazole, the triazole proton, and the methylene protons adjacent to the carbon of triazole in dendrimers $4-\mathrm{Gm}$ were found at 5.16, 7.56, and 5.43 ppm for 4-G1, 5.15,7.53, and 5.41 ppm for 4-G2, 5.11, 7.53, and 5.38 ppm for 4-G3, and 5.06, 7.49, and $5.32 \mathrm{ppm}$ for 4-G4, respectively (Figure 2 ). The peaks of the methylene protons adjacent to the oxygen of bisphenyl in dendrimers 4-Gm were found at 5.01 ppm for 4-GI, 4.98 ppm for 4-G2, 4.93 ppm for 4-G3, and 4.91 ppm for 4-G4, respectively. As the dendrimer generation increased, the peaks of all discussed protons shifted gradually to down-lield which may be influenced by the dendritic microenvironment effect. ${ }^{1.5}$ Analysis of the dendrimers by FAB or MAL .D]-TOF mass spectrometry as well as by gel-permeation chromatography (GPC) provides no signs of products with defects that would arise from incomplete coupling (Figure 3). As expected, the oblained dendrimer possessed a very well-defined molecular structure with very low polydispersity values ( $\mathrm{P}[\mathrm{D}[=1.01-1.02)$. IR data also confirmed that neither alkyne $\left(-3279 \mathrm{~cm}^{-1}\right)$ nor azide $\left(2100 \mathrm{~cm}^{-1}\right)$ residues remain in the final dendrimer (Figure 4).

Encouraged by this successlul proof of concept, we decided to apply this methodology to the synthesis of Frechet-type dendrimer containing hydrolysable amino-ester at the core. The hydrolysable dendrimer may show the characteristic potential applications such as a drug delivery system. With this in mind and as a continuation of our studies on the design and synthesis of

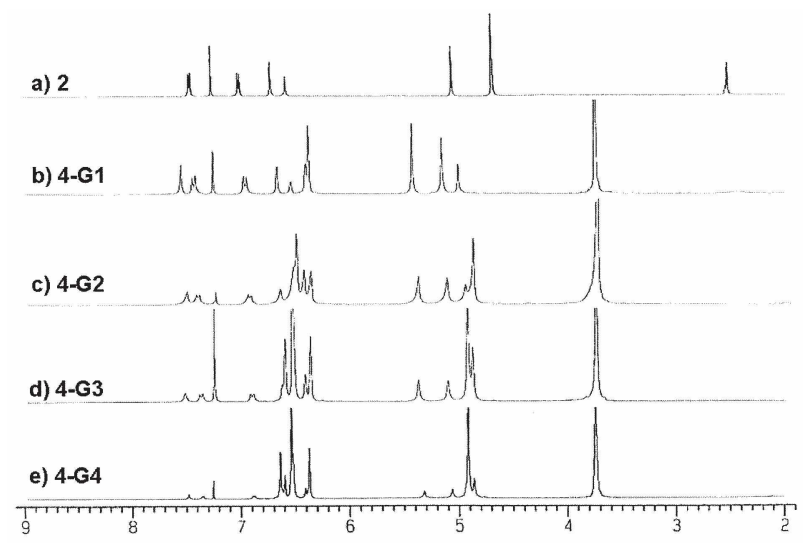

Figure 2. 'H-NMR spectra for (a) 2. (b) 4-G1. (c) 4-G2. (d) 4-G3. and (c) 4-G4.

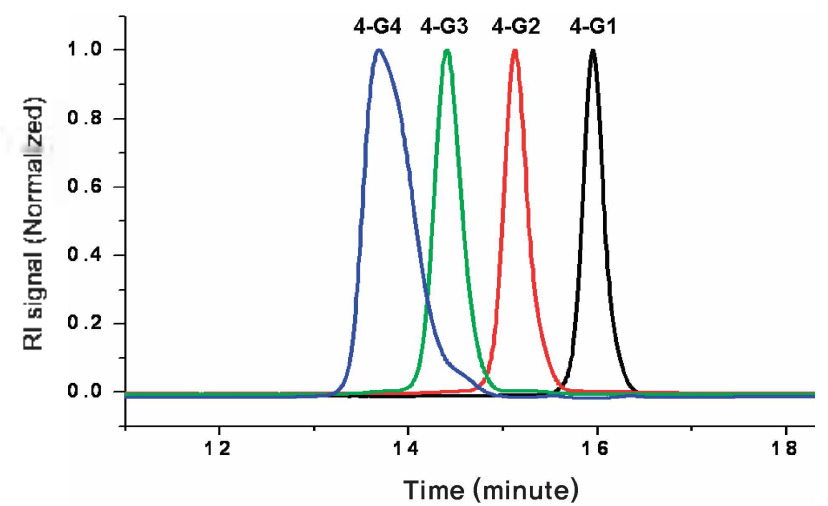

Higure 3. GlPC diagrams of dendrimers 4-Gm obtained from l'It clusnt. more applicable dendrimer, the Frechet-type dendrimers $\mathbf{5 - G m}$ with dianino-letraester unit were synthesized from the elick reaction between the azide-dendrons 1-Dm and $N, N, N^{\prime}, N^{\prime}$-tetra (prop-2-ynyloxycarbonylethyl)-1,2-diaminoethane 3 (scheme 2). After screening with several conditions using various $\mathrm{Cu}(\mathrm{I})$ sources in different solvents, the selected condition is $5 \mathrm{~mol} \%$ of $\mathrm{CuSO}_{4} \cdot 5 \mathrm{H}_{2} \mathrm{O}$ with $10 \mathrm{~mol} \%$ of sodium ascorbate with respect to the alkyne in a $4:]$ solvent ratio of $\left[\mathrm{HF}\right.$ to $\mathrm{H}_{2} \mathrm{O}$ for $5 \mathrm{~h}$ at $50{ }^{\circ} \mathrm{C}$. The reactions of the tetra(alkynes) 3 and 4.4 equiv of azidodendrons 1-D1 and 1-D2 afforded the Frechet-type dendrimers 5-G1 and 5-G2 in yiclds of 94 and $96 \%$, respectively, after $5 \mathrm{~h}$, which were separated by column chromatography. The disappearance of tetra (alkynes) $\mathbf{3}$ as well as generation and disappearance of the mono, di, and tri-triazole derivatives were also monitored by ']'LC runs of the reaction mixture. Reactions of the tetra(alkynes) 3 and 4.4 equiv of azido-dendrons 1-D3 and 1-D4 gave the frechet-type dnedrimer 5-G3 and 5-G4 in yields of 96 and $94 \%$, respectively, after $6 \mathrm{~h}$, which also were separated by column chromatography. This approach may provide new methodological insight into introduction of various functional cores and would greatly contribute to researches on the application side.

Structural characterization of the dendrimers $\mathbf{5 - G m}$ with ${ }^{\mathrm{H}} \mathrm{H}$ NMR. ${ }^{13} \mathrm{C}$ NMR, and IR spectroscopy showed complete stitching of dendrons. From the 'H NMR spectra $\left(\mathrm{CDCl}_{3}\right)$, the peaks of the methylene protons adjacent to the nitrogen of triazole, the triazole proton, and the methylene protons adjacent to the carbon of triazole in dendrimers 5-Gm were found at 5.14,

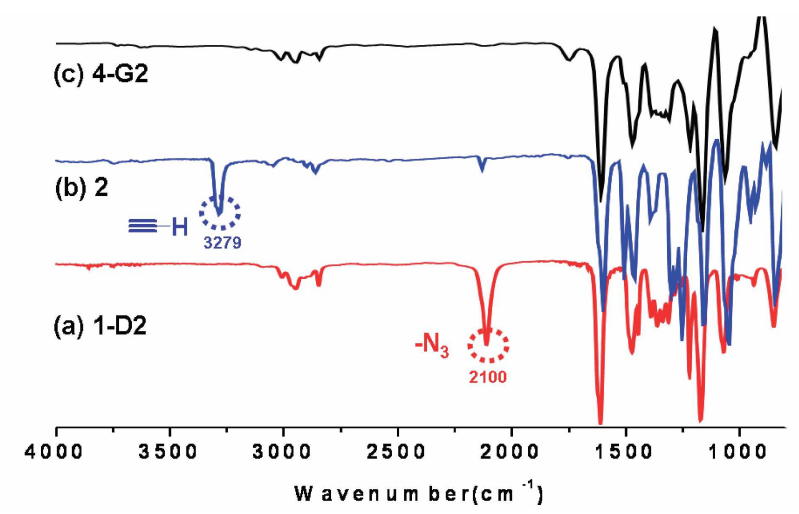

Figure 4. IR spectra lor (a) I-D2. (b) 2. and (c) 4-Ci2.

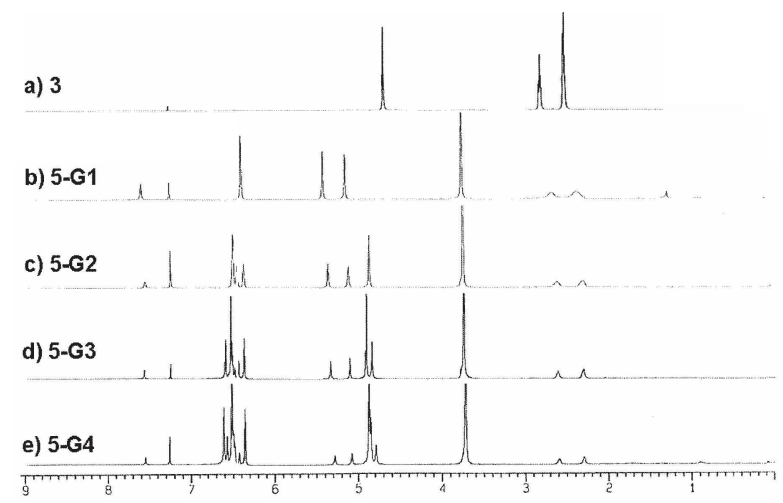

Figure 5. 'I1-NMR spectra for (a) 3. (b) 5-G1. (c) 5-G2. (d) 5-G3. and (c) 5-G4. 


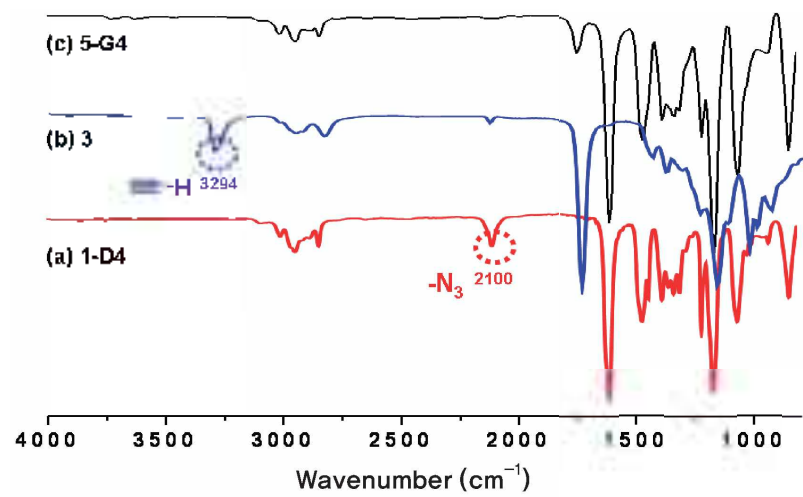

Figure 6. I. W. Lee et al

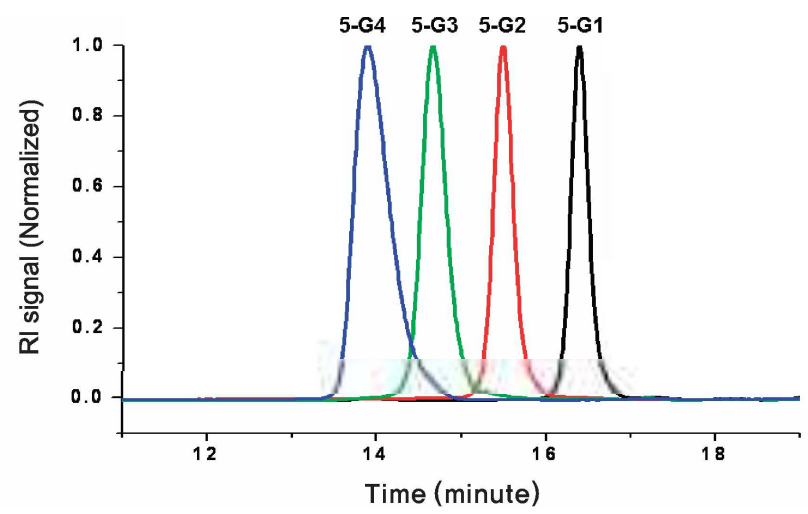

Figure 7 , J. W. I.ee et al.

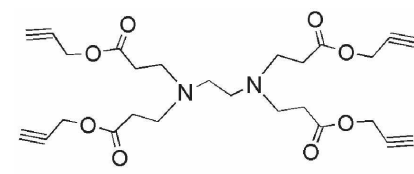

$+$

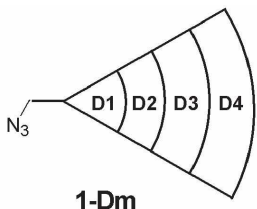

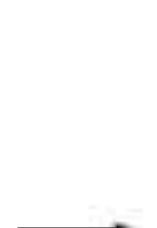

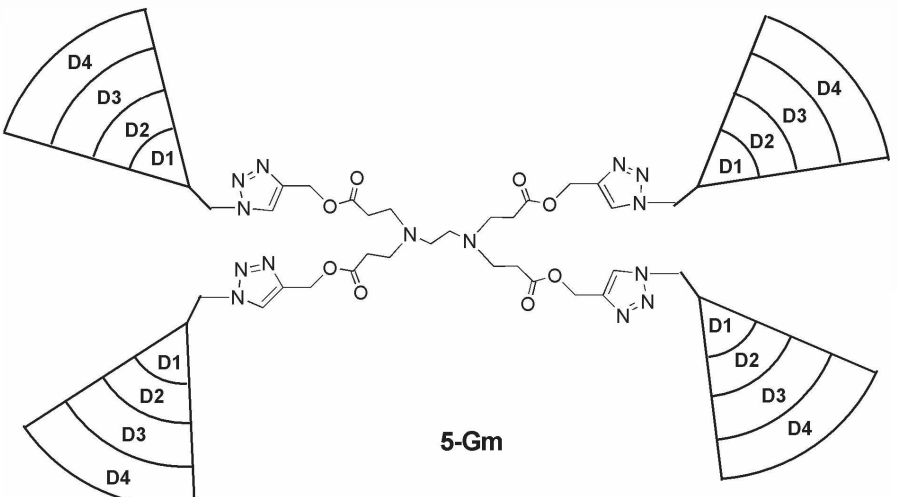

Scheme 2. Reagents and condifions: 20 mol $\%$ of $\mathrm{CuSO}_{4}-5 \mathrm{H}_{2} \mathrm{O} / 40 \mathrm{~mol} \%$ of sodium ascorbatc. $\mathrm{THF} / \mathrm{H}_{2} \mathrm{O}(4: 1), 50^{\circ} \mathrm{C}$.

7.60, and 5.4I ppm for 5-G1, 5.13. 7.56, and 5.37 ppm for 5-G2, 5.11, 7.57. and 5.34 ppm for 5-G3. and 5.08. 7.55. and 5.28 ppm for 5-G4. respectively (Figure 5).

$A$ s the dendrimer generation increased. the peaks of all methylene protons shilted gradually to down-lield which may be influenced by the dendritic microenvironment effect. ${ }^{13}$ The IR spectra shows the disappearance of the acelylene peak at $\sim 3294 \mathrm{~cm}^{-1}$ and the azide peak at $\sim 2100 \mathrm{~cm}^{-1}$ in the final dendrimer (Figure 6) while the ${ }^{1} \mathrm{H}$ NMR revealed no alkyne peak at around $82.47 \mathrm{ppm}$ (Figure 5). Analysis of the dendrimers by $\mathrm{F} A \mathrm{~B}$ or $\mathrm{M} A \mathrm{LD} \mathrm{L}-\mathrm{TO}$ mass spectrometry as well as by gel-permealion chromatography (GPC) provides no signs of products with defects that would arise from incomplete coupling (figure 7). As expected. the obtained dendrimer possessed a very well-delined molecular structure with very low polydispersity values $(P[)[=1.01-1.02)$.

In summary, we have demonstrated that click reactions between the tetra(alkynes) core and the azide-functionalized Frechet-lype dendrons lead to the formation of symmetric Frechet-type dendrimers in high yields. This method can be applied for the fast synthesis of Frechet-type dendrimers with functional units at core and may then provide an insight into designing various dendrimers with the functional cores.

\section{Experimental Section}

'[ ] NMR spectra were recorded on a 300 or 500 M] [7. NMR spectrometer using the residual proton resonance of the solvent as the internal standard. Chemical shifts are reported in parts per million (ppm). When peak multiplicities are given. the fol-

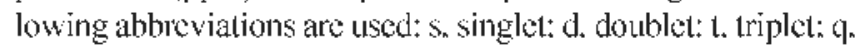
quartet: quin. quintet: $d$ of $d$. doublet of a doublet: m. multiplet; br. broad. ${ }^{1.3} \mathrm{C}$ NMR spectra were proton decoupled and recorded on a 75 or $125 \mathrm{MIJ}$ NMR spectrometer using the carbon signal of the deuteraled solvent as the intemal standard. $\mathrm{FAB}$ and MAL.D] mass spectra were obtained from Korea Basic Science Institute (KBSI) in Daegu or Daejeon and POSTECH. Flash chromatography was perlonned with 37-75 $\mu \mathrm{m}$ silica gel. Analytical thin layer chromatography was performed on silica plates with $\Gamma_{2,5+}$ indicator and the visualization was accomplished by UV lamp or using an iodine chamber. Polydispersity (PDI) of dendrimers was determined by gel permeation chromatography (GPC) analysis relative to polystyrene calibration (Agilent 1100 scries GPC. Plgel $5 \mu \mathrm{m}$.MIXED-C. refractive index detector) in TIJF solution.

General procedure for the preparation of dendrimers 4-Gm from azide- dendrons 1-Dm and tetra(alkynes) 2 . A mixture of azido-dendrons 1-Dm (0.22 mmol) and 4,4 -(3,5-bisipropargyloxy)benzyloxy)bisphenyl $2\left(0.05\right.$ mmol) in DMF- $\mathrm{H}_{2} \mathrm{O}$ $(4: 1,1 \mathrm{~mL})$ in the presence of $\left.\left.20 \mathrm{~mol} \% \mathrm{CuSO}_{4} \cdot 5\right]_{2} \mathrm{O}\right)$ with 40 mol \% sodium ascorbate was stirred at $50^{\circ} \mathrm{C}$ for $-7 \mathrm{~h}$. I he reaction mixture was poured into brine $(20 \mathrm{ml}$ ) and the resulting solution was extracted with EtOAc $(20 \mathrm{~mL} \times 3)$. The combined organic phase was dried with sodium sulfalc. concentrated. and purified by column chromatography to afford the desired product.

4-GI. $A$ yellowish oil: $96 \%$ yield: IIR 3009. 2947. 2839. 
1597. 1458. 1211, 1157, $1057 \mathrm{~cm}^{-1}:{ }^{1} \mathrm{H}$ NMR $(300 \mathrm{MHz}$. $\left.\mathrm{CDCl}_{3}\right) 83.74(\mathrm{s.} 2+\mathrm{H}) .5 .0 \mathrm{l}(\mathrm{s} .+\mathrm{H}) .5 .16(\mathrm{~s} .8 \mathrm{H}) .5 .43(\mathrm{~s} .8 \mathrm{H})$. $6.39(\mathrm{~m} .8 \mathrm{H}), 6.41(\mathrm{~d}, J=1.5 \mathrm{~Hz}, 4 \mathrm{H}), 6.55(\mathrm{~m} .2 \mathrm{H}) .6 .67(\mathrm{~m}$, $4 \mathrm{H}) .6 .97(\mathrm{~d} . J=8.5 \mathrm{~Hz}, 4 \mathrm{H}) .7 .44(\mathrm{~d} . J=8.5 \mathrm{~Hz} .4 \mathrm{H}), 7.56(\mathrm{~s}$, $4 \mathrm{H}):{ }^{13} \mathrm{C} \mathrm{NMR}\left(75 \mathrm{MHz}, \mathrm{CDCl}_{3}\right)$ oj5 $4.7,55.8,62.5,70.1,100.9$. $101.7,106.5 .106 .9,115.5,123.2 .128 .1 .134 .0,136.9,140.1$.

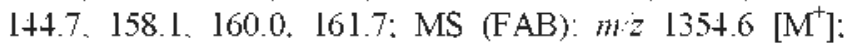

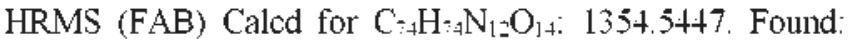
$1355.5527\left[\mathrm{M}^{-}+\mathrm{H}\right]$. PDI: 1.01 .

4-G2. A yellowish oil: $96 \%$ yield: IR 3009. 2940. 2839. 1597. 1458. 1204, 1150, $1049 \mathrm{~cm}^{-1}$ : ${ }^{l} \mathrm{H}$ NMR (300 MHz. $\left.\mathrm{CDCl}_{3}\right) 83.76(\mathrm{~s} .48 \mathrm{H})+.9 \mathrm{l}(\mathrm{s} . \mathrm{l} 6 \mathrm{H})+4.98$ (s. $\left.4 \mathrm{H}\right) .5 .15$ (s. $\left.8 \mathrm{H}\right)$. $5.41(\mathrm{~s} .8 \mathrm{H}), 6.40(\mathrm{~m}, 8 \mathrm{H}), 6.46(\mathrm{~m} .8 \mathrm{H}), 6.52-6.55(\mathrm{~m}, 22 \mathrm{H})$. $6.67(\mathrm{~m}, 4 \mathrm{H}), 6.95(\mathrm{~d} J=8.4 \mathrm{~Hz}, 4 \mathrm{H}) .7 .42(\mathrm{~d}, J=8.4 \mathrm{~Hz}, 4 \mathrm{H})$. 7.53 (s. $4 \mathrm{H}) ;{ }^{13} \mathrm{C} \mathrm{NMR}\left(125 \mathrm{MHz}, \mathrm{CDCl}_{3}\right) 854.6 .55 .8 .62 .4$. 70.1. 70.5. 100.4, 101.7. 102.7. 105.7, 107.0, 107.6. 115.5. 123.3. 128. 1. 134.0, 137.0, 139.2, 140.2, 144.6, 158.1, 160.0, 160.8

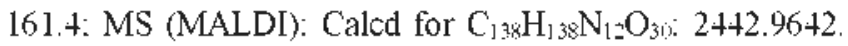
Found: $\left.2481.8971 \mathrm{MM}^{-}+\mathrm{K}\right]$. PDI: 1.01 .

4-G3. A yellowish oil: $95 \%$ yield; IR 3009. 2940.2839. 1597. 1458, 1204, 1150, $1049 \mathrm{~cm}^{-1}$ : ${ }^{1} \mathrm{H}$ NMR $(300 \mathrm{MHz}$. $\left.\mathrm{CDCl}_{3}\right) 33.74$ (s.96H). 4.88 (s. $\left.16 \mathrm{H}\right)+4.93$ (s. 36H), 5.11 (s. $8 \mathrm{H}) .5 .38(\mathrm{~s} .8 \mathrm{H}), 6.38(\mathrm{~m} . \mathrm{l} \mathrm{H}), 6.43(\mathrm{~m} .8 \mathrm{H}), 6.54(\mathrm{~m} .46 \mathrm{H})$, $6.61(\mathrm{~m}, 16 \mathrm{H}) .6 .64(\mathrm{~m}, 4 \mathrm{H}) .6 .91(\mathrm{~d} . J=8.2 \mathrm{~Hz}, 4 \mathrm{H}) .7 .38$ (d.

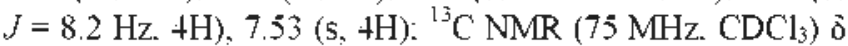
54.7 .55 .7 .62 .3 .70 .0 .70 .4 .100 .3 .101 .6 .102 .1 .102 .6 .105 .6 . $106.7,107.0 .107 .5,115.5,123.5 .128 .1 .133 .9,137.0,139.3$. 139.5. 1+0.1, 14.6. 158.1, 159.9. 160.5, 160.7, 161.4 MS(MALDI): Calcd for $\mathrm{C}_{266} \mathrm{H}_{266} \mathrm{~N}_{12} \mathrm{O}_{63}: 4619.8031$. Found: $4643.6601 \mathrm{M}^{+}+$ $\mathrm{Na}+\mathrm{H}]$. PDI: 1.01

4-G4. A yellowish oil: 97\% yield: IR 3009. 2940. 2839. 1597. 1458. 1204, 1150, $1049 \mathrm{~cm}^{-1}$ : ${ }^{l} \mathrm{H}$ NMR $(500 \mathrm{MHz}$. $\left.\mathrm{CDCl}_{3}\right) \delta 3.74$ (s. 192H) 4.86 (s. $16 \mathrm{H}$ ). 4.91 (s. $100 \mathrm{H}$ ) 5.06 (s. $8 \mathrm{H}) .5 .32(\mathrm{~s} .8 \mathrm{H}), 6.38(\mathrm{~m} .32 \mathrm{H}) .6 .42(\mathrm{~m} .8 \mathrm{H}) .6 .53-6.55(\mathrm{~m}$. $9+\mathrm{H}), 6.61(\mathrm{ml} \mathrm{l} / \mathrm{H}), 6.63-6.65(\mathrm{~m}, 36 \mathrm{H}), 6.89(\mathrm{~d}, J=8.4 \mathrm{~Hz}$. $4 \mathrm{H}) .7 .36(\mathrm{~d} . J=8.3 \mathrm{~Hz} .4 \mathrm{H}) .7 .49(\mathrm{~s} .4 \mathrm{H}):{ }^{13} \mathrm{C} \mathrm{NMR}(75 \mathrm{MHz}$. $\mathrm{CDCl}_{3}$ ) 854.4. 55.7, 62.3, 70.4, 100.3. 102.0, 102.5. 105.7. $106.8,107.5,115.4 .123 .4,128.0 .133 .9,137.3 .139 .3,139.55$. $139.61,140.1,144.6,158.1,159.9,160.5 .160 .7 .161 .4: \mathrm{MS}$

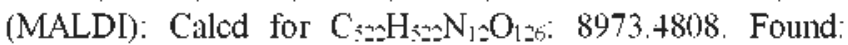
8999.7983 [M-Na+3H]. PDI: 1.02

General procedure for the preparation of dendrimers 5-Gm from azidedendrons 1-Dm and tetra(allynes) 3. A mixture of azidodendrons 1-Dm $\left(0.22 \mathrm{mmol}\right.$ ) and $\mathrm{N}, \mathrm{N}, \mathrm{N}$,. $\mathrm{N}^{\prime}$-tetra (prop2-y'ryloxycarbonylethyl)-1.2-diaminoethane $3(0.05 \mathrm{mmol})$ in $\mathrm{THF}-\mathrm{H}_{2} \mathrm{O}(4: 1,1 \mathrm{~mL})$ in the presence of $20 \mathrm{~mol} \% \mathrm{CuSO}_{4}$. $5 \mathrm{H}_{2} \mathrm{O}$ with $40 \mathrm{~mol} \%$ sodium ascorbate was stirred at $50^{\circ} \mathrm{C}$ for $\sim 6 \mathrm{~h}$. The reaction mixture was poured into brine $(20 \mathrm{~mL})$ and the resulting solution was extracted with EtOAc $(20 \mathrm{~mL} \times 3)$. The combined organic phase was dried with sodium sulfate. concentrated, and purified by column chromatography to afford the desired product

5-G1. A yellowish oil: 94\% yield: IR 3009. 2955. 2839. 1736. $1597,1466,1204.1157 .1057 \mathrm{~cm}^{-1}:{ }^{l} \mathrm{H}$ NMR $(300 \mathrm{MHz}$. $\left.\mathrm{CDCl}_{3}\right) \hat{0} 2.3+(\mathrm{m}, \mathrm{l} 2 \mathrm{H}) .2 .64(\mathrm{~m} .8 \mathrm{H}) .3 .73$ (s. $\left.24 \mathrm{H}\right) .5 .14$ (s. $8 \mathrm{H}) .5 .41$ (s. 8H), 6.39 (5. 12H). $7.60(\mathrm{~s}, 4 \mathrm{H}):{ }^{13} \mathrm{C}$ NMR $(75$ $\left.\mathrm{MHz}, \mathrm{CDCl}_{3}\right) \dot{0} 32.5,49.5 .51 .9,54.1,55.3 .57 .6,100.2,106.1$. 123.8. 136.6, 143.0. 161.2. 172.0: MS (FAB): $m: 1272.73$
$\left[\mathrm{M}^{+}\right]$: HRMS (FAB) Calcd for $\mathrm{C}_{6} \mathrm{H}_{3} \mathrm{~N}_{14} \mathrm{O}_{16}: 1272.5564$ Found: $1273.5644\left[\mathrm{M}^{-}+\mathrm{H}\right]$. PDI: 1.01 .

5-G2. A yellowish oil: $96 \%$ yield: IR $3009,2947,2839$. $1736,1597,1458.1204 .1150 .1049 \mathrm{~cm}^{-1}:{ }^{1} \mathrm{H}$ NMR $(300 \mathrm{MHz}$. $\left.\mathrm{CDCl}_{2}\right) \delta 2.3 \mathrm{l}-2.36(\mathrm{~m}, 12 \mathrm{H}), 2.63(\mathrm{t} . J=6.4 \mathrm{~Hz}, 8 \mathrm{H}), 3.76(\mathrm{~s}$. $48 \mathrm{H}), 4.89(\mathrm{~s}, 16 \mathrm{H}), 5.13(\mathrm{~s} .8 \mathrm{H}) .5 .37(\mathrm{~s}, 8 \mathrm{H}), 6.38(\mathrm{t} . J=1.8$ $\mathrm{Hz}, 8 \mathrm{H}), 6.46(\mathrm{~d}, J=1.7 \mathrm{~Hz}, 8 \mathrm{H}), 6.51-6.52(\mathrm{~m} .20 \mathrm{H}), 7.56(\mathrm{~s}$. $4 \mathrm{H}):{ }^{13} \mathrm{C} \mathrm{NMR}\left(75 \mathrm{MHz}, \mathrm{CDCl}_{3}\right)$ o332.6. 49.5, 51.9. 54.0. 55.3. 57.5, 70.0.99.8, 102.0, 105.2. 107.1, 123.8, 136.7, 138.7. 143.1, 160.2, 160.9, 172.1: MS (MALDI): Calcd for $C_{126}$

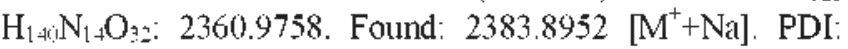
1.01

5-G3. A yellowish oil; $96 \%$ yield; IR $3009,2940,2839$. 1736. 1597, 1458. 1204. 1150. $1049 \mathrm{~cm}^{-1}:{ }^{1} \mathrm{H}$ NMR (500 MHz, $\left.\mathrm{CDCl}_{2}\right) 82.30-2.32(\mathrm{~m}, 12 \mathrm{H}) .2 .62(\mathrm{~m} .8 \mathrm{H}) .3 .75(\mathrm{~s} .96 \mathrm{H}), 4.85$ (s, 16H), 4.92 (s, 32H). 5.11 (s. 8H). 5.34 (s. 8H). 6.38 (m. $16 \mathrm{H}), 6.45(\mathrm{~m}, 8 \mathrm{H}), 6.50(\mathrm{~m}, 4 \mathrm{H}) .6 .52(\mathrm{~d} J=1.9 \mathrm{~Hz}, 8 \mathrm{H}), 6.54$ $(\mathrm{d}, J=1.8 \mathrm{~Hz}, 32 \mathrm{H}) .6 .61(\mathrm{~d}, J=1.6 \mathrm{~Hz}, 16 \mathrm{H}) .7 .57(\mathrm{~s} .4 \mathrm{H}):{ }^{12} \mathrm{C}$ NMR $\left(75 \mathrm{MHz}, \mathrm{CDCl}_{3}\right) \delta 32.6,49.6,51.8,53.9,55.3,57.5$. $70.0 .99 .8 .101 .6,101.9,105.2,106.4 .107 .1 .123 .9 .136 .8,138.8$. 139.1, 143.1, 160.0, 160.2, 160.4, 160.9, 172.2: MS (MALDI): Calcd for $\mathrm{C}_{25} \mathrm{H}_{268} \mathrm{~N}_{14} \mathrm{O}_{64}: 4537.8147$. Found: $4564.7682\left[\mathrm{M}^{-}+\right.$ $\mathrm{Na}+3 \mathrm{H}] . \mathrm{PDI}: 1.01$

5-G4. A yellowish oil: 94\% yield: IR 3009, 2940, 2839. $1736,1597,1458.1204 .1150 .1049 \mathrm{~cm}^{-1}:{ }^{1} \mathrm{H}$ NMR $(500 \mathrm{MHz}$. $\left.\mathrm{CDCl}_{3}\right) \delta 2.29(\mathrm{~m} .12 \mathrm{H}) .2 .59(\mathrm{~m} .8 \mathrm{H}) .3 .71$ (s. 192H). 4.79 (s. $16 \mathrm{H}), 4.85(\mathrm{~s}, 32 \mathrm{H}) .5 .87(\mathrm{~s} .64 \mathrm{H}), 5.08(\mathrm{~s}, 8 \mathrm{H}) .5 .28(\mathrm{~s}, 8 \mathrm{H})$, 6.36 (n. $32 \mathrm{H}), 6.43(\mathrm{~m}, 8 \mathrm{H}) .6 .48-6.52(\mathrm{~m} .88 \mathrm{H}), 6.58(\mathrm{~m}$, $20 \mathrm{H}), 6.6 \mathrm{l}(\mathrm{m}, 32 \mathrm{H}), 7.55(\mathrm{~s},+\mathrm{H}):{ }^{13} \mathrm{C} \mathrm{NMR}\left(\mathrm{I} 25 \mathrm{MHz}, \mathrm{CDCl}_{2}\right)$ ô32.6. 49.5. 52.0. 53.9, 55.2, 57.5, 69.85, 69.93. 99.8. 101.6, $101.8,105.0,105.2$. 106.4. 107.1, 123.9. 136.9. 138.8, 139.1. 139.2, 143.1. 160.0, 160.2, 160.9. 172.1: MS (MALDI): Calcd for $\mathrm{C}_{5] 11} \mathrm{H}_{3}{ }_{2} \mathrm{~N}_{14} \mathrm{O}_{128}$ 8891.4925. Found: $8894.6192\left[\mathrm{M}^{-}+3 \mathrm{H}\right]$. PDI: 1.02 .

Acknowledgments. This research was supported by the Dong-A University: Research Fund.

\section{References}

1. Grimsdale, A. C.; Mullen, K. Angew. Chent Int. Ed. 2005, 4t, 5592.

2. Tomalia, D. A. Prog. Polm. Sci. 2005, 30, 294

3. Hawker, C. T. Frechet, T. M. J. J. Am Chem Soc. 1990, 112, 7638.

4. Grayson. S. M.: Frechet. J. M. I. Chem. Rev 2001. 101.3819.

5. (a) Rostontsev, V. V.; Green, L. G.; Fokin, V. V; Sharpless, K. B. Angew: Chem. Int Ed 2002, 41, 2596. (b) Tomoe, C. W: Christensen, C.; Meldal, M. J. Org. Chent 2002, 67, 3057.

6. (a) Wu, P.; Feldman, A. K.; Nugent, A. K.; Hawker, C. . .; Scheel. A.; Voit, B; Hy un, T.: Frechet, I. M. J.; Sharpless, K. B.; Folin, V. V. Angew: Chent. Int. Ed 2004, 43, 3928. (b) Malkoch, M: Schleicher, K; Drochermuller, E; Hawker, C. J.; Russell, T. P;: Wu. P.: Fokin, V. V. Aacromolecules 2005, 38, 3663. (c) Joralemon, M. T.; O'Reilly, R. K.; Matson, T. B.; Nugent, A. K.; Hawker, C. T. Wooley, K. L. Macromolecules 2005, 38, 5436. (d) Rijkers, D. T. S.: van Esse, G. W.: Merkx, R.; Broluwer, A. J; Jacobs, H. J. F.: Pieters, R. J.: Lishamp, R. M. J. Chen Conmm. 2005,4581. (e) Wu, P.; Malkoch, M.: Hunt, J. N.: Vestberg, R:; Kaltgrad. E.: Finn. M. G.: Fokin. V. V.: Shanpless. K. B.: Hawker. C. T. Chem. Conmmon 2005, 5775. (f) Femandez-Megia, E: Conea, I.: Rodngulez-Meizoso, I.: Riguera, R. Macromolecules 2006, 39,2113 
7. (a) Lee, J. W: Kin, B. K. Bull Korean Chem. Soc. 2005, 26,658 . (b) Lee, J. W. Kim, B. K.: Jin, S. H. Bull. Korean Chem. Soc. 2005, 26, 833. (c) Lee, J. W: Kin, B. K.; Kim, I. H.: Shin, W. S.; Tin, S. H. Bull. Korean Chem. Soc. 2005, 26, 1790. (d) Lee, J. W: Kim, B. K. Sinthesis 2006, 615. (e) Lee, T. W. Kim, T. H. Kim. B. K.; Shin, W. S.: Tin, S. H. Tetrahedron 2006, 62, 894. (f) Lee, T. W: Kin, B. K.: Kim, H. T: Han, S. C.: Shin, W. S. Tin, S. H. Hacromolecules $2006,39,2418$. (g) Lee, J. W.; Kim, J. H.; Kim, B. K. Tetrahedron Lett. 2006, 47, 2683 (h) Lee, J. W. Kim. B. K: Kin, T. H.; Shin, W. S.; Jin, S. H. J. Org. Chem. 2006, 71, 4988. (i) Lee, I. W.: Kim, I. H: Kin, B. K.: Kim, T. H.; Shin, W. S.; Tin, S. H. Tetrahedron 2006, 62,9193. (j) Lee, I. W.; Kim, J. H.; Kim, B. K.; Kim, T. H.; Shin, W. S.; Jin, S. H.; Kim, M. Bull. Korean Chem. Soc. 2006, 27, 1795 (k) Lee, J. W. Kim, J. H.; Kim, H. J.; Han, S. C.: Kim, J. H.: Shin, W. S., Tin, S. H. Bioconingate Chem. 2007, 18, 579. (1) Lee, T. W: Han, S. C.: Kinn, J. H.: Ko, Y. H.: Kim, K. Bull Korean Chem. Soc. 2007, 28, 1837. (m) Lee, I. W.: Kim, H. J: Han, S. C.; Kim, J. H.; Jin, S. H. J. Pol, .m. Sci. Pant A: Polvm. Chem 2008, 16. 1083 .

8. (a) Hehns, B.; Mynar, J. L.; Hawker, C. T.: Frechet, T. M. T. J. Am. Chem. Soc. 2004, 126, 15020. (b) Mvnar, J. L.; Choi, T.-L.; Yoshida, M.; Kim, V: Hawker, C. J : Frechet, T. M. I. Chen. Commun. 2005, 5169 .

9. (a) Hawker, C. I.: Wooley, K. L. Science 2005, 309, 1200. (b)
O'Reilly, R. K.: Joralemon, M. T.; Hawker, C. J.: Wooley, K. L. Chem. Eur. J. 2006, 12, 6776. (c) Nandivada, H.: Chen, H.-Y, Bondarenko, L.: Lahann. I. Angew: Chem. Int. Ed. 2006. 45. 3360. (d) Moses, T. E:; Moorhouse, A. D. Chent. Soc. Rev. 2007, 36,1249 .

10. (a) Lu, G.; Lam, S.; Burgess, K. Chem Commm 2006, 1652. (b) Laurent. B. A: Gravson. S. M. J. Am. Chem. Soc. 2006, 128. 4238. (c) Ladmiral, V.; Mantovani, G.; Clarkson, G. J; Cauet, S.; Irvin, I. L.: Haddleton, D. M. J. Ant. Chent Soc: $2006,128,4823$. (d) Vogt, A. P.: Sumerlin, B. S. Aacromolecules 2006, 39, 5286. (e) Karim, M. A.: Cho. Y.-R.: Park, J. S.: Kim. S. C.: Kim. H. J.: Lee, I. W. Gal, Y.S.: Tin, S. H. Chem Conmm 2008, 1929. (f) Foumier, D.; Hoogenboom, R.; Schubert U. S. Chem. Soc. Rev. 2007, 36, 1369. (g) Lutz, J.-F. Angew: Chen. Int. Ed. 2007, 46, 1018. (h) Binder, W. H.: Sachsenhofer, R. Macromol. Rapid Commm 2007, 28, 15 .

1 1. (a) Bock, V. D.; Hiemstra, H.; van Maarseveen, J. H. Eur. J. Org. Chem. 2006, 51 .

12. Lee, J. W.: Han, S. C.: Lee, Y.-g.; Kim, T. H.: Oh, I. Bull Koiean Chem. Soc. 2008. 29. 1055 .

13. (a) Mong, T. K.-K; Niu, A.; Chow, H.-F.; Wu, C.; Li, L.; Chen, R. Chem. Eur. J. 2001, 7, 686 (b) Wong, C.-H, Chow, H.-F.: Hui, S.-K.: Sze, K.-H. Org. Lett. 2006, 8, 1811, (c) Sun, H.; Kaifer. A. E. Org. Lett. 2005. 7.3845. 